\title{
Mycorrhizal Inoculation for Increasing the G2 Seed Bulbs Production of Potato Granola L Varieties from Mini Cuttings
}

\author{
Noertjahyani $^{1 *}$, G. Ramadhan ${ }^{1}$, Ai Komariah ${ }^{1}$, E. Roosma Ria ${ }^{1}$ and E. Masnenah ${ }^{1}$ \\ Date Received: 15 th December 2019 / Date Accepted: $26^{\text {th }}$ January 2020
}

\begin{abstract}
Purpose : Mycorrhizae are mutualistic symbiosis or association between soil fungi and plant roots which plays an important role in increasing nutrient availability and crop productivity. Potatoes are one of the carbohydrate-producing plants and it can be propagated with mini cuttings from plantlets. The application of mycorrhizal inoculant is expected to increase the yield of potato from mini cuttings. The research was conducted to investigate the effect of mycorrhizal inoculants on degree of root colonization, growth and yield seed of Granola L potato propagated with mini cuttings. The study aimed to increase potatoes seed productivity by application of mycorrhizal inoculant.
\end{abstract}

Research Method: The experiment used was Randomized Block Design consist of six treatments $(0,5 \mathrm{~g}, 10 \mathrm{~g}$, $15 \mathrm{~g}, 20 \mathrm{~g}$, and $25 \mathrm{~g}$ per plant), and repeated 4 times. The observed responses were degree of roots infection, plant height, leaf number, plant dry weight, the number of tubers and tuber yield.

Findings : The results showed that the application of mycorrhizal inoculants was able to increase root colonization by $344 \%$ and plant dry weight by $47.49 \%$. Application of $15 \mathrm{~g} /$ plant mycorrhizal inoculants increased the plant height at 6 and 8 week after planting by 23.92\%,16.24\%, respectively and tuber yield per plant by $24.96 \%$. These results confirm that the application of $15 \mathrm{~g}$ per plant mycorrhizal inoculants can be used to enhance the productivity of potato seeds.

Limitations : Mycorrhizal colonization was highly affected by the soil physico-chemical properties, the active ingredients and quality of inoculants.

Value : This research contribute to increase seed production of potato.

Keywords: mini cuttings, mycorrhizal inoculants, potatoes seed, Granola, tuber yield

\section{INTRODUCTION}

Potatoes (Solanum tuberrosum L.) are a group of vegetables as an alternative of carbohydratesource and are of high economic value and are quite stable. Potato cultivation has an important meaning in supporting food diversification programs for the realization of food security and agribusiness development programs to increase farmers' incomes. Domestic demand for potatoes continues to increase in line with population growth, and the growing industry of potato-based. Potatoes are also a non-oil export commodity. This is caused by, among others, the use of less qualified seeds.

Potato production is relatively increasing and more than 150 countries are growing potatoes.
In 2017, more than 19 million ha of potatoes were harvested worldwide and the production was 388.19 million metric tons (Statista, 2019). The biggest producer in the world is China (Shahbandeh, 2019)

Potato production in Indonesia in 2018 only reached $1,284,760$ tons with a harvest area of 68,683 ha and productivity of 18.71 tons ha $^{-1}$ with a harvest area of 68,683 ha and productivity of 18.71 tons $^{-1}{ }^{-1}$ (Statistical Central Berau and Directotare of Horticultura, 2019)

\footnotetext{
1* Department of Agrotechnology, Agricultural Faculty Universitas Winaya Mukti, Indonesia.

noertjahyani@yahoo.com
}

(D) ORCID http://orcid.org/0000-0003-0360-593X 
The level of productivity of potatoes in the developing countries is still low (less than 20 tons $\mathrm{ha}^{-1}$ ) when compared to China and Europe which have achieved an average productivity of 40-50 tons ha-1 (Wang, 2008). This is caused by, among others, the use of less qualified seeds due to the limited availability of certified superior varieties of seeds and also the high price of seeds. The need for potato seeds per hectare is 32,000 seeds or 1.0-1.5 tons. The use of certified potato seeds in Indonesia is still seldom. The need for national seeds has only reached about $10 \%$ and the rest is imported. To increase potato production through area expansion will increase the need for seed tubers.

Propagation of potato production of one of them is by tubers. The process of seed tuber production must go through a long stage starting from the production of mini cuttings from plantlets, mini tuber Go production in the screen house and planted to produce $\mathrm{G}_{1}$ seed bulbs and so on until $\mathrm{G}_{3}$. To accelerate the mass production of $\mathrm{G}_{2}$ seed bulbs, it can be done through multiplication of miniature micro propagation cuttings which is directly from vessel tissue culture. The propagation method, besides being fast, plants stay healthy and inexpensive (Haapala, 2017).

Increased seed productivity from mini cuttings is processed by applying biological fertilizers, such as mycorrhizae. Mycorrhizae has been widely reported to increase soil $\mathrm{P}$ availability, increase P uptake by plants, plant growth and productivity (Weber, et al., 1992; Li, et al., 2006; Lone, et al., 2015; Ergin and Gulser, 2016). However, its cultivation and role are influenced by land management such as the use of inorganic and organic fertilizers (Indriani, et al., 2006; Mashfufah and Prasetya, 2019) so as to affect plant growth and productivity. The use of mycorrhizae in multiplication of potato seeds with mini cuttings is expected to increase the growth and productivity of potato plants. Therefore, the aim of this research is to study the effects of mycorrhizal dose in influencing the growth and productivity of potato seed tubers from mini cuttings in an effort to increase the production of potato seed tubers $\mathrm{G}_{2}$.

\section{MATERIALS AND METHODS}

The study used an experimental method in the plastic house of the Research Station, Faculty of Agriculture, Universitas Winaya Mukti, Tanjungsari-Sumedang, West-Java, Indonesia. The altitude of the trial site locates about 850 $\mathrm{m}$ above sea level. The used material was potato seeds in the form of mini cuttings from the Granola L. planlet. The cultivar plantlet was from the Lembang Vegetables Research Institute. The planting medium uses a layer of tillage $(0-20 \mathrm{~cm})$ of the Andisols Tanjungsari. Other materials used are inoculant mycorrhizae Mikofer (mixture of genus Glomus sp and Gigaspora sp. with 52 spore density per g inoculant) produced by PT Kelola Bumi Nusantara Bogor, NPK 16-16-16 fertilizer, pesticides, organic fertilizer for sheep manure. The tools used include analytical scales for measuring plant dry weights; oven to obtain dry stover; Binocular microscopes, test tubes, water baths, tweezers, pipettes, scissors, glass objects and glass covers that are needed for observation of mycorrhizal colonization.

The experimental treatment was repeated four times with the dose of mycorrhizal inoculants consist of: $0,5 \mathrm{~g}, 10 \mathrm{~g}, 15 \mathrm{~g}, 20 \mathrm{~g}$, and $25 \mathrm{~g}$ per plant, respectively. Application of inoculant was given at the planting hole and carried out at planting at the appropriate dose of treatment. The planting used media were a mixture of topsoil and organic fertilizer of sheep dung with a volume ratio of $2: 1$. Polybags containing planting media as much as $4 \mathrm{~kg}$. Seeds, in the form of 10-day-old mini-cuttings, are planted on polybags (as in Figure 01 and Figure 02). Plant maintenance process includes watering, weeding, fertilizing and controlling pests and diseases so that the plants can well grow. Watering was done every day until the condition of the planting medium field capacity. NPK fertilization with a dose of $3 \mathrm{~g}$ per plant was carried out at 2 and 4 weeks after planting (WAP). Fertilization was done after weeding. Weed is mechanically controlled. Pest and disease control is done if there are symptoms of an attack. Harvesting is done 80 days after planting. 


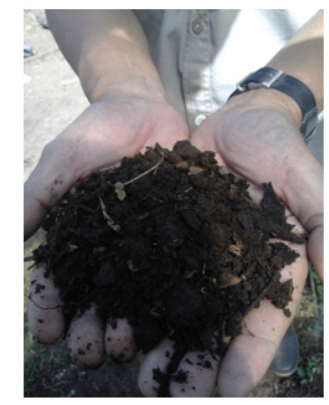

(a)

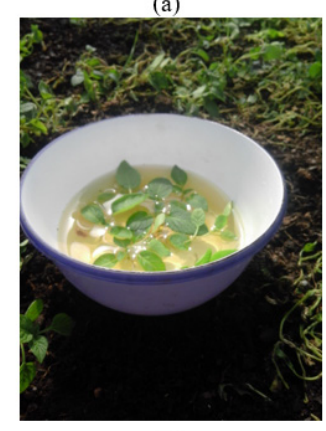

(d)

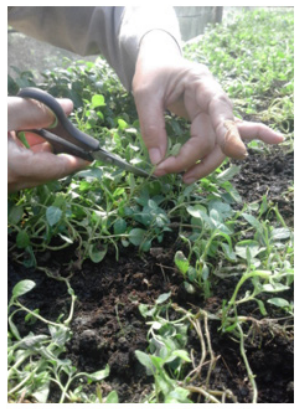

(b)

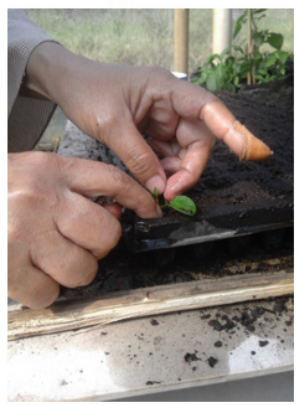

(e)

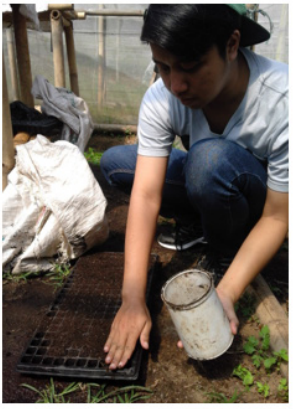

(c)

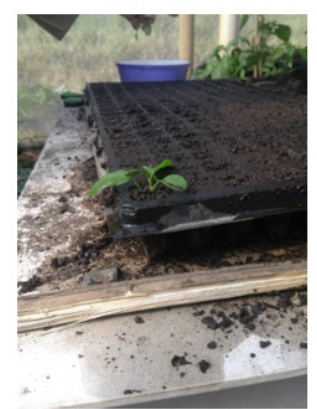

(f)

Figure 01: Preparation of mini cutting (a) plant media, (b) planlet, (c) tray for mini- cutting, (d) mini cutting soak with nutrient solution, (e) planted the mini cutting, (f) tray with seedling from mini cutting

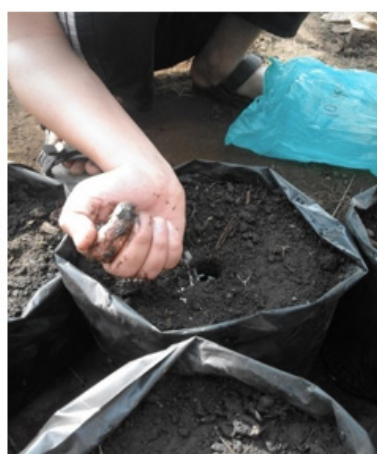

(a)

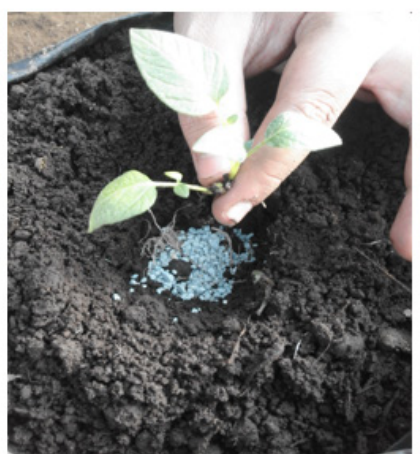

(b)

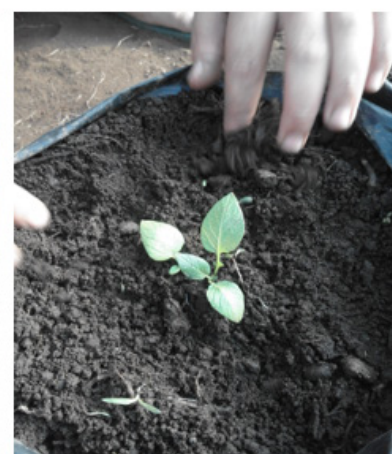

(c)

Figure 02: The stages of planting seed potato from mini cutting in polybag, (a) mycorrhizal inoculant application in the planting hole of the polybag, (b) planting seed 10 days old from mini cutting, (c) young potato plant

Plant response data due to treatment was the average of measurements of 3 sample plants obtained by simple random sampling. The effect of mycorrhizal dose on mycorrhizal colonization with plant roots, growth and productivity of potato plants of the Granola variety was carried out with Fisher's exact level of 5\% test. To find out the mycorrhizal inoculation treatment that can give the highest tuber productivity was done by Duncan Test of 5\% significance level.

Plant response due to the mycorrhizal inoculation treatment on plant height, number of leaves at 2, 4, 6 and 8 WAP (weeks after planting) are observed. Mycorrhizal colonization with plant roots was done at the age of 6 WAP. Root staining using fuchsin acid, carried out before observing the roots under a microscope with a magnification of 400 times. Root colonization $(\%)$ obtained from infected root samples divided by all observed root samples multiplied by $100 \%$. Observations of fresh plant weight, plant dry weight, number of tubers, tuber diameter, and tuber weight per plant, and tuber size were carried out after harvest. Tuber size is the result of the distribution of tuber weights per plant by the number of tubers. Soil as a growing medium was analyzed by $\mathrm{pH}$, media, organic $\mathrm{C}$ and $\mathrm{P}$ available. 


\section{RESULTS AND DISCUSSION}

The growing media has a $\mathrm{pH}$ of 7.18 (neutral), $9 \%$ organic carbon (very high), and available $\mathrm{P}$ at $330 \mathrm{ppm}$ (very high). Growing media for the growth of potatoes from mini cuttings, including fertile. Neutral acidity is a very good condition for nutrient availability. This is evident from the availability of soil $\mathrm{P}$ is very high. High organic carbon (9\%) will improve soil structure, and thus soil biology. This organic carbon is a source of energy and nutrients for soil biology (especially heterotrophic microorganisms), so that the biological activity of the soil will increase soil chemical fertility.

Plant height 2 WAP and 4 WAP between without or with mycorrhizal inoculation showed that plant height was not significantly different. Similarly, between mycorrhizal inoculation treatments, their effect on plant height was not significantly different. Different effects were seen in plant height of 6 WAP and 8 WAP. Higher plant height was found in plants that were inoculated with $15 \mathrm{~g}$ of mycorrhizae per plant (Figure 03) although not significantly different from plants without mycorrhizal inoculation, 5 g per plant and $20 \mathrm{~g}$ per plant.

In contrast to plant height, the number of leaves and fresh weight of the plant were not affected by mycorrhizal treatment (Figure 04 and Table 01). However, the root colonization and plant dry weight of mycorrhizal application showed its effect. Mycorrhizal inoculation can increase the percentage of root colonization 2-3 times. There was an increased dry weight on mycorrhizal application $15 \mathrm{~g} /$ plant (Table 01). The figures in the column followed by the same letters in Table 01 and Table 02, show no significant difference based on DMRT level of $5 \%$.

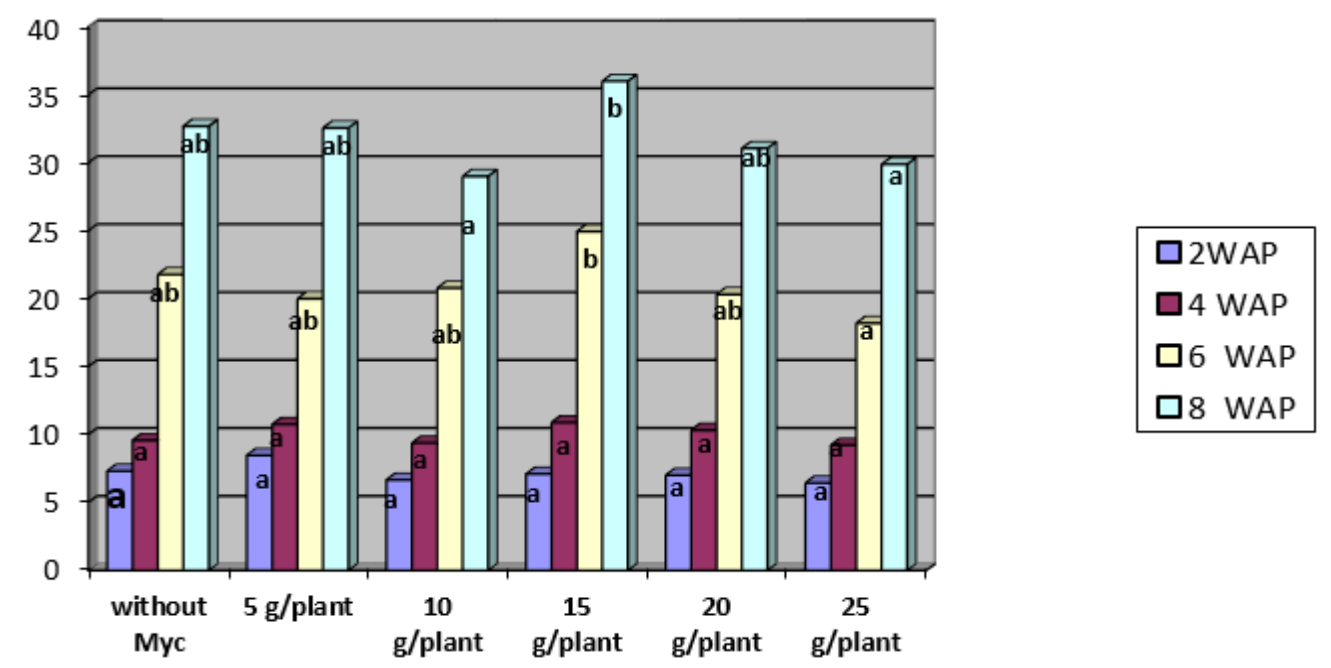

Figure 03: Potato plant height $(\mathrm{cm})$ at 2, 4, 6 and 8 WAP treated with mycorrhiza

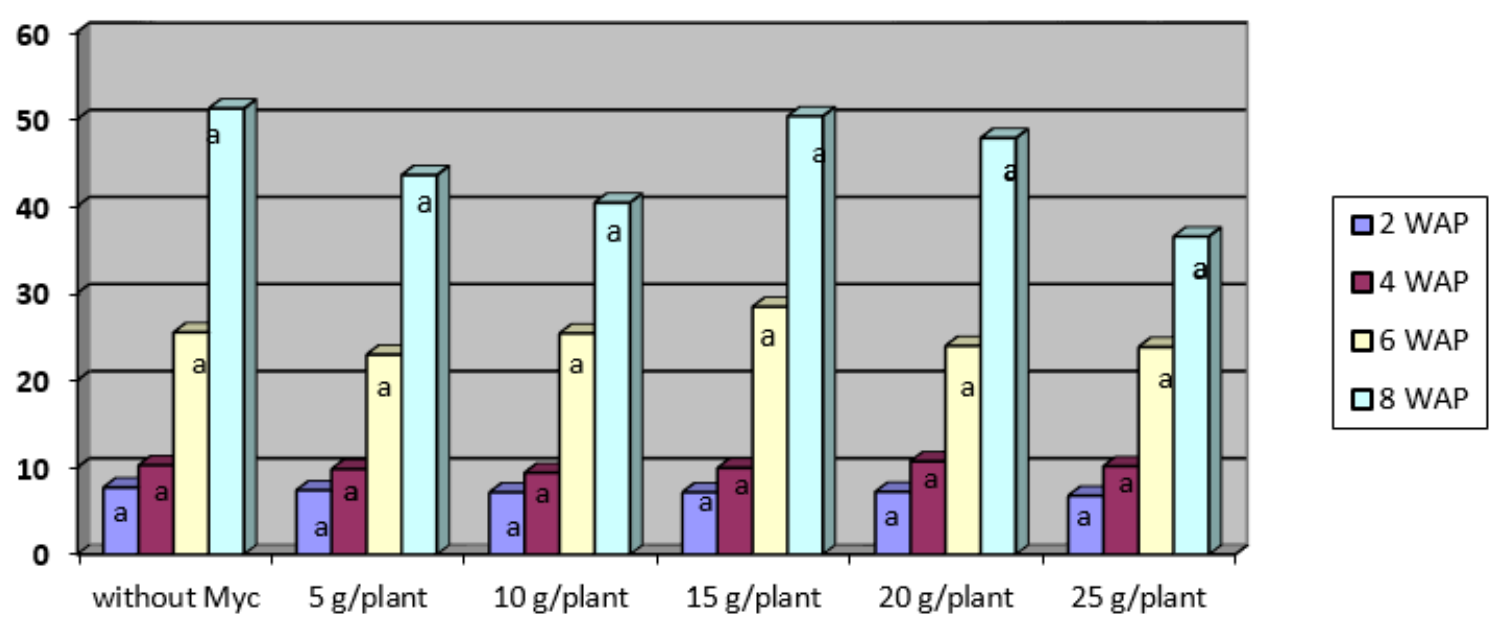

Figure 04: Potato leaves number at 2,4,6 and 8 WAP treated with mycorrhizae 
Tabel 01: Root colonization, fresh weight, and plant dry weight of potato $G_{2}$ from mini cutting treated with mycorrhizal inoculant

\begin{tabular}{cccc}
\hline Mycorrhiza rate & Root Colonization (\%) & Plant Fresh Weight $(\mathrm{g})$ & Plant Dry Weight $(\mathrm{g})$ \\
\hline 0 g/plant & $6.25 \mathrm{a}$ & $16.67 \mathrm{a}$ & $6.23 \mathrm{a}$ \\
$5 \mathrm{~g} /$ plant & $25.00 \mathrm{~b}$ & $25.31 \mathrm{a}$ & $8.59 \mathrm{ab}$ \\
10 g/plant & $26.25 \mathrm{~b}$ & $17.50 \mathrm{a}$ & $8.78 \mathrm{ab}$ \\
$15 \mathrm{~g} /$ plant & $31.25 \mathrm{~b}$ & $21.25 \mathrm{a}$ & $10.91 \mathrm{~b}$ \\
20 g/plant & $30.00 \mathrm{~b}$ & $20.42 \mathrm{a}$ & $7.82 \mathrm{ab}$ \\
25 g/plant & $26.25 \mathrm{~b}$ & $17.81 \mathrm{a}$ & $7.35 \mathrm{ab}$ \\
\hline
\end{tabular}

Table 02: Tuber Diameter, tuber weight, number of tuber and $G_{2}$ tuber yield of potato from mini cutting treated with mycorrhizal inoculant

\begin{tabular}{ccccc}
\hline Mycorrhiza rate & $\begin{array}{c}\text { Tuber Diameter } \\
(\mathrm{cm})\end{array}$ & $\begin{array}{c}\text { Weight of tuber } \\
(\mathrm{g})\end{array}$ & Number of tuber & $\begin{array}{c}\text { Tuber yield per } \\
\text { plant }(\mathrm{g})\end{array}$ \\
\hline $0 \mathrm{~g} /$ plant & $2,89 \mathrm{a}$ & $6,91 \mathrm{a}$ & $6.25 \mathrm{a}$ & $32.66 \mathrm{a}$ \\
$5 \mathrm{~g} /$ plant & $1.77 \mathrm{a}$ & $7.61 \mathrm{a}$ & $7.00 \mathrm{a}$ & $52.86 \mathrm{~b}$ \\
$10 \mathrm{~g} /$ plant & $1.71 \mathrm{a}$ & $5.51 \mathrm{a}$ & $8.23 \mathrm{a}$ & $53.39 \mathrm{~b}$ \\
$15 \mathrm{~g} /$ plant & $1.90 \mathrm{a}$ & $8.67 \mathrm{a}$ & $6.81 \mathrm{a}$ & $55.15 \mathrm{~b}$ \\
$20 \mathrm{~g} /$ plant & $1.75 \mathrm{a}$ & $6.12 \mathrm{a}$ & $7.13 \mathrm{a}$ & $42.53 \mathrm{ab}$ \\
$25 \mathrm{~g} /$ plant & $1.85 \mathrm{a}$ & $7.98 \mathrm{a}$ & $5.77 \mathrm{a}$ & $46.49 \mathrm{ab}$ \\
\hline
\end{tabular}

Mycorrhizal application has no effect on yield components (diameter, number of tubers, and tuber weights). Tuber productivity per plant between mycorrhizal inoculated plants and those that do not, give the same effect. Without mycorrhizal inoculation it gave lower tuber productivity than others treatment. Mycorrhizal inoculation of $5 \mathrm{~g}$ per plant, $20 \mathrm{~g}$ per plant and 25 g per plant gave better yield (Table 02 ).

Mycorrhizae have been known to be associated with $80 \%$ of plant roots, including potato plants. The experimental results appear that without inoculation of mycorrhiza a root infection occurred of $6.25 \%$ (Table 01$)$. This might happen, because there are indigenic mycorrhizae in the media which then infect the roots of plants. The percentage of root infections due to mycorrhizal inoculation ranged from $25-31.25 \%$ (low), but increased 3-fold compared without mycorrhizal inoculation. The low root infection caused by $\mathrm{P}$ is available in very high growing media so that it inhibits the development of mycorrhizae. The conditions of organic $\mathrm{C}$ and $\mathrm{P}$ available are very high causing the growth of hyphal propagules, spore germination, initiation of colonization (Becerra, et al., 2005), and mycorrhizal hypa density (Kobae, 2016; Mai, et al., 2018) will decrease.
Mycorrhizal inoculation had no effect in increasing plant height 2 and 4 WAP, respectively, number of leaves, plant fresh weight, tuber diameter, tuber weight, and number of tubers. Adding manure / organic material to the planting media will cause an increase in $\mathrm{pH}$ so that the availability of nutrients (macro and micro) is optimal. Phosphorus is an essential macro nutrient and not a car, which plays a role in energy transfer and protein metabolism in plant growth and growth. At very high available $\mathrm{P}$, mycorrhizal inoculation does not increase $\mathrm{P}$ absorption by plants. Low mycorrhizal infection does not cause differences in absorption of nutrients by plants. Therefore, the presence of mycorrhizae did not significantly affect plant height, number of leaves, plant fresh weight, and yield components when compared without mycorrhizal inoculation. Mycorrhizal application has a positive effect on $\mathrm{P}$ uptake in low-available P-soils (Weber, et al., 1992; Ergin and Gulser, 2018).

Plant height of 6 and 8 WAP, plant dry weight, and tuber yield per plant showed different responses due to mycorrhizal application. Mycorrhizal inoculation can increase plant height, plant dry weight and tuber yield per plant up to a certain dose. Application of $15 \mathrm{~g}$ 
per plant had a better effect on plant height of 6 and 8 WAP, plant dry weight and tuber yield per plant, with an average increase of $23.92 \%$, $16.24 \%, 47.49 \%$ respectively, and $24.96 \%$. Some of the results of research that strengthen it are Ortas (2010); Aguk (2013); Mau and Utami (2014); Susiani, et al., 2018).

Higher tuber yields per plant in mycorrhizal application of $15 \mathrm{~g}$ per plant supported by a higher plant height, a higher number of tubers and a larger tuber size / weight. This is consistent with the results of Arslan's research (2007), that plant height, number of tubers per plant and tuber weight were positively correlated to tuber yields per plant with correlation values of $0.715,0.809$ and 0.939 , respectively. Productivity per plant has a direct effect $(56.5 \%)$ on yield per hectare. Based on experimental results prove that the application of mycorrhizae has a positive effect on the tuber productivity of potato plants.

\section{CONCLUSIONS}

The application of mycorrhizal inoculant (MI) was able to increase mycorrhizal colonization by threefold, plant height growth 6 and 8 weeks after planting, plant dry weight and tuber productivity per plant. Application of $15 \mathrm{~g} \mathrm{MI}$ per plant increased plant height 6 and 8 WAP, plant dry weight, and tuber productivity per plant by $23.92 \%, 16.24 \%, 47.49 \%$ and $24.96 \%$, respectively. Application of $15 \mathrm{~g}$ MI per plants can be recommended for increasing potato productivity in the production of G2 tuber seeds. This finding contributes to increase seed production of potato.

\section{Data Availability Statement}

The datasets generated during and/or analysed during the current study are available from the corresponding author on a reasonable request.

\section{ACKNOWLEDGMENT}

The author would like to thank the Dean of the Agricultural Faculty, Universitas Winaya Mukti for allowing to use the Research Station and Basic Laboratory facilities in conducting research.

\section{REFERENCES}

Aguk, J. A. (2013). Evaluate the effect of arbuscular mycorrhizal fungi and rhizobacteia inoculation on performance of potato (Solanum tuberosum). Thesis for the degree of Sustainable Soil Resource Management in the Department of Land Resource Management and Agricultural Technology, University of Nairobi. pp.105

Arslan, B. (2007). Relationships among yield and some yield characters in potato (Solanum tuberosum L). Journal of Biological Sciences. 7(6):973-976. DOI: https://doi.org/10.3923/ jbs.2007.973.976

Becerra, A., Macelo R. Zak, Thomas R. Horton, and Jorge Micolini. (2005). Ectomycorrhizal and Arbuscular mycorrhizal colonization of Alnus acuminate from Calilegua National Park (Argentina). Journal of Mycorrhiza 15:525-531. Available https://link.springer.com/ article/10.1007/ s00572-005-0360-7 . DOI: https://doi.org/10.1007/s00572-005-0360-7

Ergin, S.F. and Fusun Gulser. (2016). Effect of mycorrhiza on growth criteria and phosphorus nutrition of lettuce (Lactuca sativa L.) under different phosphorus application rates. Eurasian Journal of Soil Science, 5 (4):275-278 . DOI: https://doi.org/10.18393/ejss.2016.4.275-278

Haapala, Tapani. (2017). In expensive mass propagation techniques for introducing improved potato varieties in the tropics. Echo Asia Notes. Ed. Abram Bicksler and Daniela Riley. Issue 32:1-4A 
Indriani, N.P., Mansyur, Iin Susilawati, Lizah Khairani. (2006). The effect of organic matter, mycorrhizae and rock phosphate on production and phosphor absorption of tropical kudzu (Pueraria Phaseoloides Benth). Journal of Ilmu Ternak, 6 (2):158-162 https://adoc.tips/ nyimas-popi-indriani-mansyur-iin-susilawati-lizah-khairani-f.html

Irwan, A.W. and A. Wahyudin. (2017). The effect of dosage of arbuscular vesicular mycorrhiza and liquid fertilizer complement on growth yield components and yield of soybean on Inceptisols Jatinangor. Journal of Kultivasi, 16 (2): 326-332. http://jurnal.unpad.ac.id/kultivasi/article/ view/ 19583/pdf. DOI: https://doi.org/10.24198/kultivasi.v16i2.13856

Kobae, Yoshihiro. (2016). Phosphate treatment strongly inhibits new arbuscule development but not the maintenance of arbuscule in mycorrhizal rice roots. Plant Physiology Preview. American Society of Plant Biologists. All Rights Reserved. Plant Physiology. Vol. 171: 566579 DOI: https://doi.org/10.1104/pp.16.00127

Li, H., Sally E. Smith, Robert E. Holloway, Yongguan Zhu, and F. Andrew Smith. (2006). Arbuscula mycorrhizal fungi contribute to phosphorus uptake by wheat grown in phosphorus-fixing soil even in the absence of positive growth responses. New Physiologist. 172:536-543. DOI: https://doi.org/10.1111/j.1469-8137.2006.01846.x

Lone, R., Razia Shuab, Vandna Sharma, Vijay Kumar, Rayees Mir, and K.K. Koul, (2015). Effect of arbuscular mycorrhizal fungi on growth and development of potato (Solanum tuberosum) plant. Asian Journal of Crop Science 7 (3): 233-243. DOI: https://oi.org/10.3923/ ajcs.2015.233.243

Mai, W., Xiangrong Xue, Gu Feng, and Changyan Tian. (2018). Simultaneously maximizing root mycorrhizal growth and phosphorus uptake by cotton plants by optimizing water and phosphorus management. BMC Plant Biology 18:334 10 pages. DOI: https://doi.org/10.1186/ s12870-018-1550-8

Mau, A. E. and S.R. Utami. (2014). Effects of biochar amendment and arbuscular mycorrhizal fungi inoculation on availability of soil phosphorus and growth of maize. Journal of Degraded and Mining Lands Management. 1 (2): 69-74. DOI: https://doi.org/10.15243/ jdmlm.2014.012.069

Ortas, I. (2010). Effect of mycorrhiza application on plant growth and nutrient uptake in cucumber production under field conditions. Spanish Journal of Agriculture and Research. 8 (S1), S116-S122. DOI: https://doi.org/10.5424/sjar/201008s1-1230

Shahbandeh, M. (2019). Global potato production from 2002-2017. https://www.statista.com/ statistics/ 382174/global-potato-production/

Statista. (2019). Potato production worldwide from 2002-2017. https://www.statista.com/statistics/ 382174/global-potato-production/

Statistical Central Berau and Directorate General of Horticulture (2019). Production, harvest area and productivity of vegetable in Indonesia. www.pertanian.go.id

Susiani, P., I. Rukmi, and S.N. Jannah. (2018). Applications of mycorrhiza on potato growth and productivity. IOP Conf. Series: Journal of Physics: Conf. Series 1217 (2019) 012143. DOI: https://doi.org/10.1088/1742-6596/1217/1/012143

Wang, F. (2008). The importantance of quality potato seed in increasing potato production in Asia and the Pasific region. http://www.fao.org/3/i0200e/I0200E10.htm 
Weber, E., E. George, Douglas P. Beck, Mohan C. Saxena. (1992). Vesicula arbuscular mycorrhiza and phosphorus uptake of chickpea grown in Northern Syria. Export Agriculture 28 (4):433442. Published online by Cambridge University Press: 03 October 2008. DOI: https://doi. org/10.1017/S001447900020147. 